\title{
How groups reach agreement in risky choices: an experiment*
}

\author{
Jingjing Zhang \\ Marco Casari
}

11 March 2009

\begin{abstract}
:
This paper studies how groups resolve disagreement when they must reach unanimity after submitting individual proposals and exchanging text-form messages via a chat window in lottery choice experiments. We find that the majority proposal does not always prevail. The minority proposal prevails sometimes, especially when it is closer to risk neutrality. About one third of the groups disagrees after communication and would have got zero payoffs if disagreement remains after two more attempts without communication. In these groups, extrovert subjects are more likely to lead the group outcome than confused or conscientious subjects. Overall group choices are more coherent and closer to risk neutrality than individuals'. Checking the recorded messages, we find that the chat activity is intense, growing with the level of disagreement and aims at finding consensus. The amount and timing of chat messages help us to predict which choice prevails in the group.
\end{abstract}

JEL Classifications: C92, D81

Keywords: risk attitude, group decision making, communication, experiments

\footnotetext{
* J.Zhang, McMaster University, Department of Economics, 1280 Main Street West, Hamilton, ON, L8S 4M4, Canada, phone +1-905-525-9140 ext 24527, fax +1-905-521-8232, jjzhang@mcmaster.ca; M.Casari, University of Bologna, Department of Economics, Piazza Scaravilli 2, 40126 Bologna, Italy, phone +39-051-209 8662, fax +39051-2098493 marco.casari@unibo.it. This project was developed while both authors were at Purdue University, which provided an excellent research environment. We thank Anya Savikhin for valuable research assistance, Christine Jackson for the financial support, Tim Cason for comments on an earlier version of the paper as well as seminar participants at the IMEBE meeting in Alicante, Spain, Capua LabSì meeting, Italy, ESA meeting in Lyon, France.
} 


\section{Introduction}

In an experiment we study decision-making procedures of individuals versus groups when facing lottery choices. Eliciting risk attitudes for groups was initiated in management (Stoner, 1961; Pruitt, 1971; Lamm and Myers, 1978) and recently involved also economists (i.e. Shupp and Williams, 2008, Baker et al., 2008). When a group decides whether to enter a lottery or not, there is no obvious correct choice and individuals may legitimately differ in their proposals due to their preferences. For this reason the psychological literature on groups and teams would classify this task as "judgmental". ${ }^{1}$ On the contrary, "intellective" tasks have a demonstrably correct solution. Examples are beauty contest games (Kocher and Sutter, 2005) and common value auctions (Cox and Hayne, 2006). The only intellective aspect of our lottery task is that choices should be coherent or monotonic.

Existing experimental studies on lottery choices made by groups have two main interests: detecting "risky shifts" and examining the improvement in the coherency of choices. Earlier studies from the management literature introduced the concepts of risky shifts and cautious shifts. "Risky shift" denotes situations where groups make riskier decisions than individuals, and "cautious shift" otherwise.

This study has a novel design and a different focus in comparison with existing studies. Our aim is to understand in greater detail how groups deal with disagreement. We keep a record of group communication and use it in data analysis; we also adopt a strong unanimity rule to create common interest within group members, which has not been employed in other studies.

Through the group process, we find that lottery choices become more coherent and closer to risk neutrality. In resolving disagreement the majority proposal quite often prevails, although there are some interesting personality and demographic effects, which we report in detail below.

The remainder of the paper is organized as follows. Section 2 reviews literature. Section 3 describes experimental design and procedures. Section 4 reports the results. Section 5 concludes.

\section{Literature Review}

This section focuses on four recent papers that examine decisions made by groups facing risky choices, Harrison et al. (2005) Shupp and Williams (2008), Baker et al. (2008), Masclet et al. (2009). Table 1 presents a design comparison with the present study. All studies, including ours, compare lottery choices of groups of three members with individuals choosing in isolation.

\footnotetext{
${ }^{1}$ Other judgmental tasks are ultimatum and trust games, which involve social preferences (Bornstein and Yariv, 1998, Cason and Mui, 1997).
} 
In both treatments subjects face the same set of lottery choices $(8,9,10$, or 15) and identical monetary incentives. At the end of the session, only one of the lotteries is randomly selected for payment.

Shupp and Williams (2008), Baker et al. (2008), Masclet et al. (2009) all find that groups are more risk averse than individuals. On the contrary, Harrison et al. (2005) report no group effect. This might be due to the different rule Harrison et al. (2005) implement to determine the group decision. Instead of using a unanimous rule, each group voted for the lottery they preferred under a majority voting rule in Harrison et al. (2005). As Baker et. al. (2008) note, the unanimity rule is more likely to induce more pressure toward uniformity in groups than the majority rule.

Among existing studies of group risk attitude, the present paper is novel in at least three important aspects. First, a written record of the communication among group members is obtained. As a result, we can analyze communication to understand internal dynamics of the group and to explain differences in outcomes. Second, before group members communicate and then make their anonymous choices privately, we elicit individual proposals and posted them for the group to see. Third, we employ a novel rule to deal with disagreement.

Existing studies exhibit a significant diversity in design along a number of dimensions (Table 1). The most interesting differences in the studies pertain to group interaction. First, Masclet et al. (2009) randomly change group composition for each lottery choice while the others keep it fixed. This generates different dynamic incentives to "tune-in" with the group. Second, communication ranges from none, to anonymous chat rooms, to face-to-face interaction. We know from experiments on social dilemmas that communication can have profound effects on choices. ${ }^{2}$ With lottery choices, the issue is not much free riding but rather preference aggregation. The role of communication is then more to exchange information about intended choices and eventually to reach an agreement, given that the instructions in all studies call for a unanimous group decision. Different communication protocols offer specific technologies to exchange information. A face-to-face communication presents opportunities for strong personalities to dominate group discussion and for biases due to appearance or other "distractions." It also lowers anonymity because people can recognize friends or talk with group members after the experiment. On the contrary, chat communication offers more equal access to the discussion floor and high levels of anonymity. Another dimension of communication is the

\footnotetext{
${ }^{2}$ It has been documented in the experimental literature that pre-play face-to-face communication significantly improves cooperation in public good game (for instance Isaac and Walker, 1988; Cason and Khan, 1999) and common-pool resource experiments under conditions of heterogeneity in resource endowment and payoffs (Hackett et al., 1994).
} 
degree to which it is structured. In our study there was a compulsory pre-communication stage where subjects wrote their proposed choice for everyone to see.

Although often downplayed in experiments with groups, the default choice when a group does not reach unanimity is theoretically extremely important. Each of the studies adopts a different criterion to resolve disagreement: random choice, majority rule, mean choice, no choice. The "no choice" default is often employed also in the field, where a group does not take a stand nor bid in an auction unless agreement is reached. We now discuss the implicit incentives that different default rules generate for group discussion. Let us adopt the standard assumption that subjects have well-defined preferences toward risk and assume that they are informed about the intended choices of others in their group. The last column of Table 1 lists whether a subject would benefit from successfully persuading others to change their intended choice ("talk"). It may be that all three group members have different opinions or that there is a majority of two versus a minority of one. All default rules exhibit positive incentives to talk, except majority rule, where if you are already part of the majority you do not have any incentive to persuade others. Another crucial aspect is the incentives to "listen," given that you have well-defined preferences. No default rule has positive incentives to listen except the one in our study. In that case if the group reaches no unanimous decision, no decision is placed, so earnings are zero for everyone in the group. Such a default rule sets the highest incentives both to "talk" and to "listen" to other group members. Of course, there may be other types of advantages from listening to others besides those considered in Table 1. Communication may enhance the understanding of the task as well as learning about the intended choices of others and so benefit everyone in the group. Table 1 considers incentives under the more narrow view of rational subjects endowed with precise utility functions, which are common knowledge.

Some experiments employ a within-subject design and others a between-subject design. The former allows a more direct comparison of choices in isolation (I) and in group (G) but may exhibit order effects. To control for order effects, Masclet et al. (2009) run sessions with I-G and G-I sequences and do not find any. A between-subject design relies instead on an assumption of similar preferences of the two experimental samples for I and for G treatments.

Other experimental studies have groups facing more challenging choices under risk. Rockenbach et al. (2007) compare individuals and groups with respect to choices among alternative financial investments and find that groups accumulate significantly higher expected values at a significantly lower total risk. Charness and Karni (2007) study choice monotonicity over lottery and bayesian updating by individuals and groups. They find that social interaction 
reduces violation rates and thus groups make substantially fewer errors than individuals and the error rate decreases with group size.

\section{Experimental Design and Procedures}

Each session involved four parts plus a questionnaire and involved 15 participants. Overall 120 students participated in the experiment. In part 1, we measured subjects' risk attitude with fifteen binary choices between lotteries. In part 2 subjects were randomly divided into groups of three persons and faced the same task as in part 1. We report results of parts 3 and 4, which involved a different task, in Casari, Jackson, and Zhang (2009). The overall incentive structure was similar to that in Holt and Laury (2002). Subjects chose between a "safe" Option A and a "risky" Option B. The payoff for Option A was deterministic (50 tokens) and the payoff for Option B was either 150 or 0 . On the first decision the probability of the high payoff (150)

for Option B was zero. In subsequent choices, the probability of the high payoff increased by $1 / 20$ each line, $0,1 / 20, \ldots, 14 / 20$. A risk neutral person would choose option A in lotteries one through seven and then switch to option B in lottery eight. Risk seeking agents may switch to option B earlier than lottery 7 and risk averse agents may switch later than lottery 7 . Any rational agent should choose option A over option B in the first lottery (50 vs. 0 francs always) and later on eventually switch to option B. Multiple switches would be a signal of confusion. We paid only one of the fifteen decisions, chosen randomly at the end of the session. Random choices were all implemented through drawings from a bingo cage.

In part two there were five groups in each session. There were a proposal phase, a chat phase, and a group choice phase. Everyone simultaneously made an individual proposal about each of the fifteen lottery choices. Then any line with disagreement was highlighted for all three group members to see. At this point, participants could switch to a chat window and had two minutes to send free-format messages to others in their group. We asked participants to follow two basic rules: (1) to be civil to one another and do not use profanities, and (2) not to identify themselves in any manner. Messages were recorded. In the chat window subjects received an id number from 1 to 3 based on the order in which they sent messages in that specific period. After the chat stage, everyone had to submit a choice for the group decision. If the choices of all three group members were identical for a specific decision line (unanimity), then we had a group choice. If there was unanimity on all fifteen choices, then part 2 was over. Otherwise, the line(s) with disagreement was (were) highlighted and all three group members were asked to submit their new proposals. If there was still disagreement, there was another, final round of proposals. At this point part 2 was over even if disagreement remained. We paid only one of the fifteen 
decisions, chosen randomly at the end of the session. Random choices were all implemented through drawings from a bingo cage. If for the line selected the group was still in disagreement, then the group earned zero for part 2 .

We distributed written instructions and read them aloud, taking questions as they arose. The experiment was performed with a z-tree application (Fishbacher, 2007). No person participated in more than one experimental session. We guaranteed a minimum payment of $\$ 5$. We converted each experimental token to an actual dollar at the rate of $\$ 0.03$. Including all parts, a session lasted on average about 2 hours and average earnings per person were about $\$ 20$. We conducted eight experimental sessions at Purdue University (USA) between September 25 and October 28, 2007. Participants were recruited from the undergraduate campus population by email.

\section{Results}

We report five main results.

\section{Result 1: The monotonicity of lottery choices improved from the individual to the} group treatment.

We employed a table format to elicit risk attitude, where a subject with monotonic risk preferences would choose option A in decision 1 and then eventually switch forever to option B at one later decision. If there were more than one switch from A to B, or if there were switches from B back to A, a subject is classified as non-monotonic, which is taken as a proxy of confusion or irrationality. Recorded levels of monotonicity in the experiment were very high, ranging from $87.5 \%$ for individual choices $(105 / 120)$ to $95.0 \%$ for group choices $(114 / 120)$. Only a small portion of this improvement can be attributed to task learning, as individual proposals for group discussion were only slightly better than individual choices $(90.0 \%$ vs. $87.5 \%)$.

Result 2: Group choices were closer to risk neutrality than individual choices. In particular, group choices exhibited a risky shift from individual choices.

Support for Result 2 comes from Table 2 and Figure 1. We discuss separately lotteries 17 from lotteries 8-15. In lotteries 1-7 only a risk seeking agent would choose the risky option B. Differences here were rather limited because risk seeking behavior was rare: on average, only $2 \%$ of individual choices and $0.4 \%$ of group choices were for B. In these lotteries, groups were more prudent than individuals. Most of the differences came from lotteries 8-15 where a risk neutral agent would choose the risky option B. In these lotteries, groups were more risky than individuals. On average, $57.4 \%$ of individual choices and $61.7 \%$ of group choices were for B. 
This difference of 4.3 percentage points may be in part explained by order effects. Part 1 elicited individual choices, part 2 elicited individual proposals and group choices. About 58.8\% of individual proposals were for B (1.4 points more than individual choices). Order effects are unlikely to explain the risky shift. First, we stated in part one of the instructions that the tasks in part one and two were the same lottery choices. Hence subjects could optimize considering the overall level of uncertainty. Second, little evidence can be traced from a comparison of the individual choices in part one with the individual proposals in part two. We elicited individual proposals before any communication could take place in the group setting and report only minimal differences with part one choices, which helps to rule out large order effects. As mentioned after Result 1, some of this difference is simply correction of non-monotonic behavior. Third, Masclet et al. (2009) studied order effects but did not find any.

Result 3: When in disagreement, the majority proposal did not always prevail. The minority proposal sometimes prevailed, especially when closer to risk neutrality. Confused as well as conscientious subjects were more likely to give in to group pressure.

We focus explicitly on group decisions where there is disagreement. We define disagreement as a situation where not all three individual proposals are equal. All groups disagree on at least one decision (Figure 2), 77.5\% found an agreement on the first round, 20\% after a second or third round, and only 2.5\% (1 group) never found an agreement. ${ }^{3}$ On average a group disagreed on 4 lottery decisions (27\% of decisions). The bulk of the disagreement (85\%) was in lotteries 8-13, where risk neutrality pointed toward option B while risk averse subjects may have preferred the safer option A (Figure 3).

The analysis of disagreement is particularly interesting because one can understand the internal process that lead to a decision and shed light on Result 2. We consider the 159 group decisions with disagreement out of 600 in order to report patterns of how disagreement was resolved through group interaction. Consider two possible benchmarks: the outcome with a dictator selected at random in the group and the outcome with majority voting. Given that the decision was binary, A or B, and a group was consisted of three individuals, there were only two possible patterns with disagreement, a majority for $A$ (AAB) or a majority for $B(A B B)$. Following a random dictator process the majoritarian proposal would prevail in $66.7 \%$ of the cases while following majority voting the majoritarian proposal would prevail in $100 \%$ of the cases. As Table 3 illustrates, when in disagreement, the majoritarian proposal prevailed in $81.1 \%$ of the decisions, while the minoritarian proposal prevailed in the remaining $18.9 \%$. Although at

\footnotetext{
${ }^{3}$ The group reached agreement on 12 of the 15 lottery choices. Analyses with 159 groups (477 proposals) dropped those 3 observations while analysis 162 groups (486 proposals) replaced those 3 group lottery choices with the individual inputs in the third attempt to reach a group decision.
} 
first glance the actual outcome seems in-between a random dictator and a majority rule process, looking more closely one can see some interesting biases in group decision making, hence the dictator here was not really random.

The types of decisions where the minoritarian proposal prevailed were peculiar and generated a shift toward risk neutrality when aggregating individual proposals into group choices. When in disagreement, $52.7 \%$ of individual proposals were the same as those of a risk neutral agent. Within the group setting, $57.2 \%$ of group decisions had a majority of risk neutral proposals (Table 3). It turned out that an even larger fraction of group choices were in accordance with risk neutrality $(61.0 \%)$ because minority proposing risk neutral choices had a higher probability of prevailing. Hence the group interaction generated a shift toward more risk neutral choices.

Table 4 presents a breakdown with respect to whether the more risky proposal prevailed. Overall, with disagreement the more risky proposal prevailed in $54.7 \%$ of the decisions, which is higher than a coin flip probability and is also higher than the decisions where the majoritarian proposal was the more risky (49.7\%). Hence, the group interaction does produce a risky shift. In particular, when the majority prevailed, in $52.7 \%$ of decisions it had the more risky position; when the minority prevailed, in $63.3 \%$ of decisions it had the more risky position.

Table 5 presents the marginal effect from a probit regression on individual proposals. The dependent variable is equal to one when an individual proposal equals the actual group choice (hence it prevails in case of disagreement). Among the independent variables, we included some aspects of lottery choices, demographic and personality traits, and chat activity. The focus is on individual proposals in disagreement with others in the group. We will postpone the discussion of chat activity to Result 4 and discuss the other findings.

The demographic variables are skill, gender and major. Skills are proxied by the ACT/SAT scores obtained from the university Registrar's Office. We have either SAT or ACT scores for $92.5 \%$ of the subjects (missing data $=0$ ), who are coded using the US nationwide distribution of the SAT-takers (College Board of Education, 2006) and ACT-takers. The threshold for high ability is being in the top quartile of the distribution and for low ability is being in the lower quartile. The variables are primarily based on SAT scores and, when missing, on ACT scores. The cutoff values are the average between male and female national tables. We have interaction terms between gender and skill. 
Another class of regressors code five personality traits using questionnaire answers. For example one variable measures conscientiousness through the average rating on nine statements. ${ }^{4}$ Subjects circle a number 1 through 5, where 1 stands for "strongly disagree," 2 for "disagree," 3 for "neutral," 4 for "agree," and 5 for "strongly agree." The other personality traits coded are agreeableness, neuroticism, openness, and extroversion.

Table 5 presents results from the same econometric specification run on five data samples. Column one includes all decisions with disagreement, columns two and three show a breakdown of the sample into cases where the majority or minority prevailed, respectively. We will later comment on the other columns. The results corroborate five points. First, there was a significant shift toward risk neutrality as stated in Result 2. Second, as already discussed, being in a majority substantially raised the likelihood to prevail in case of group disagreement. Third, subjects who are confused with the task are less likely to prevail. We proxied a subject's confusion using a lottery-specific dummy for her individual choice being different from her proposal and a subject-specific dummy for her proposal not being monotonic. Forth, personality matters, in the sense that more conscientious subjects are less likely to prevail in cases of disagreement. Fifth, skill and, to a lower extent gender, affect who prevails in group decision making. In particular, there is an adverse selection effect because low skilled subjects are more likely to prevail in cases of group disagreement. Smart females have also a slightly higher influence on group decisions.

Result 4: About one third of groups did not find agreement immediately after communication. Groups with high skill and monotonic members were more likely to find an immediate agreement as well as those with more conscientious and extrovert members.

Table 6 presents a probit regression on the difficulty of reaching a group agreement in the first attempt. Predictably, the higher the number of lotteries with disagreement the less likely the groups will resolve disagreement immediately. In addition, both skill and personality measures had an impact. Groups with members with SAT/ACT score above the $75^{\text {th }}$ percentile and with monotonic proposals were more likely to find an immediate agreement. Groups with more conscientious and extrovert members were also more likely to find an immediate agreement. There is also a strong effect of Science and Engineering although no gender effect is recorded. We will comment on the impact of chat activity in Result 5.

\footnotetext{
${ }^{4}$ I do a thorough job. I do things efficiently. I make plans and follow through. I am a reliable worker. I persevere until the task is finished. I am easily distracted. I can be somewhat careless. I tend to be lazy. I tend to be disorganized.

${ }^{5}$ Table 5B presents an alternative specification to highlight the presence of a risky shift.
} 
When disagreement persists after the communication stage, group processes may change substantially. In column four of Table 5 we restrict the sample to those groups who required multiple attempts before converging toward unanimity. Those groups faced an emergency situation since they would have obtained zero payoffs if they hadn't reached an agreement after three attempts. When disagreement is not resolved immediately, our conclusions at the end of Result 3 need qualification. Point one is no longer true, as other factors beyond risk neutrality matter more in the emergency situation. Point four acquires a different light as different personality traits prevail: extroversion has now a significant impact while conscientiousness is no longer important. On point five, the number of observations is too small to go beyond conjectures. Women seem to lose their ability to influence group decisions under an emergency.

Result 5: Chat activity was intense, growing with the level of disagreement and aimed at finding consensus. The amount and timing of chat messages helps to predict group choices.

Every one of the 120 subjects intervened in the two minutes of chat time. On average a person intervened 4.3 times and wrote a total of 23.9 words. Hence, the average length of an intervention was rather short (5.6 words). Interestingly, the higher the number of decisions with disagreement the more intense was the chat activity, suggesting that messages were aimed at finding a common ground. With more disagreements, participants intervened on average about the same number of times but with longer messages (Figure 4).

Figure 5 informs about the content of the communication by giving an uncensored list of the top 100 words employed. "A" and "B" were the option names and were among the most frequently used. In the figure, the character size is proportional to frequency of use. Notice numbers 1-15, whose sizes are roughly linked to how controversial that particular lottery decision was. "I" and "we" suggest the tension between individual and group. Overall, the words employed denote a very practical use of communication to reach consensus or express opinions for or against a choice.

The probit regressions in Tables 5 and 6 show that chat activity helps to predict how groups resolved disagreement. In Table 5 four variables summarized chat activity: who talked first, who talked last, number of words written by the subject and total number of words written by the other two people in the group. Even without analyzing the content of the messages, one can see three effects on whose choice prevailed in group decision making. First, the persuasion effort as measured by the number of words written paid off in the expected direction. Not voicing your own reasons lowered someone's chances of determining the group decision. In particular a subject in a minoritarian position had chances to convince the other two if she wrote 
longer messages. Second, talking first had a small but significant effect on leading the group to side for your own proposal. Third, in the subsample with multiple attempts before unanimity there was a shift of power towards whom talked last.

In Table 6 four other variables that are based on the count of the number of words summarized the chat activity: overall activity in the group, difference in activity between the most and least active in the group, length of the last intervention and of the second-to-last intervention. We report two major effects of chat activity on the difficulty of reaching a group agreement in the first attempt. First, groups with more words written in the chat can sort out disagreement more quickly. Second, a large inequality in chat activity among group members correlates with more difficulties of reaching a consensual group choice.

\section{Conclusions}

We study group decision making with the aim to understand how groups resolve disagreement. The experimental task is similar to previous studies on lottery choices but our focus is instead on the internal negotiation process of group decision making. We present evidence both at the aggregate and individual level.

Groups of three participants faced lottery choices and had to find unanimity in order to enter a lottery. We kept a record of group communication and used it in the data analysis. We reported that through a group process, lottery choices became more coherent and closer to risk neutrality. In resolving disagreement the majority proposal did not always prevail. There were some interesting personality and demographic effects.

Our empirical investigation yielded five main results. First, group choices were more coherent than individual choices when measured through the monotonicity over lottery choices. Adhering to monotonicity resembles an intellective task and we would expect groups to perform better than individuals, as they did. Second, group choices were closer to risk neutrality than individual choices. This aggregate result contributes to the debate on whether group decision making generates a risky or a prudent shift. Overall, our evidence brings more support in favor of group processes producing a shift toward more risky choices. The last three results yield novel insights about the black box of group processes. We elicited pre-discussion proposals and postdiscussion choices of group members and analyzed the micro-level data. The third result concerns disagreement resolution among group members. The majority proposal did not always prevail. The minority proposal sometimes prevailed, especially when it was risk neutral. When one group member was able to convince the other two, it often generated a shift toward risk neutrality. The fourth result concerns the difficulty of groups in finding an agreement. In fact, 
about one third of groups did not find an agreement immediately after communication, especially those groups with a wider initial disagreement. Lack of agreement caused an emergency situation because without unanimity in a lottery choice (either AAA or BBB), participants' payoff was zero for that lottery. Agreement could eventually be reached without further communication in a second or third attempt. In these emergency situations, the mode of interaction within group members changed substantially. Personality traits such as extroversion became more important while conscientiousness less important and the effects of skill and gender was also significantly altered.

Finally, group members could exchange messages through a chat window. We recorded the communication and evaluated its impact on the group outcome. The chat activity was intense, growing with the level of disagreement and aimed at finding consensus. The amount and timing of chat messages help to predict which choice prevailed in the group. For instance, the number of words written by a member is a proxy of her persuasion effort, which paid off in the expected direction. Instead, the person who talked last was typically either a follower who "OKs" someone else's proposal or a reluctant minority who threatened to blow up unanimity in emergency situations.

Understanding group processes in a controlled laboratory environment helps to uncover processes and biases of decision-making within firms and complex organizations. Further work in this direction promises to uncover additional valuable insights. 


\section{References}

Baker, R.J., Laury, S.K., and Williams, A.W. (2008). Comparing Small-Group and Individual Behavior in Lottery-Choice Experiments. Southern Economic Journal (forthcoming).

Casari, M., Jackson, C., and Zhang, J. (2009). Do Group Fall Prey to the Winners' Curse? working paper

Cason, T. N. and Khan, F. U. (1999). A Laboratory Study of Voluntary Public Goods Provision with Imperfect Monitoring and Communication. Journal of Development Economics, 58 (2), 533-552.

Cason, T. N. and Mui, V.-L. (1997), A Laboratory Study of Group Polarization in the Team Dictator Game, Economic Journal, 107(444), 1465-1483.

Charness, G., Karni E., and Levin D. (2007). Individual and Group Decision Making Under Risk: An Experimental Study of Bayesian Updating and Violations of First-Order Stochastic Dominance, Journal of Risk and Uncertainty, 35(2), 129-148.

College Board of Education (2006). SAT Percentile Ranks for Males, Females, and Total Group, College-Bound Seniors - Critical Reading + Mathematics + Writing.

Cooper, D. J. and Kagel, J. H. (2005). Are Two Heads Better than One? Team Versus Individual Play in Signaling Games, American Economic Review, 95 (33), 477-509.

Cox, J.C. and Hayne, S. C. (2006). Barking Up the Right Tree: Are Small Groups Rational Agents? Experimental Economics, 9(3), 209-222.

Davis, J. H. (1992), Some Compelling Intuitions about Group Consensus Decisions, Theoretical and Empirical Research, and Interpersonal Aggregation Phenomena: Selected Examples, 1950-1990. Organizational Behavior and Human Decision Processes, 52, 3-38.

Devine, D. J. and Philips, J. L. (2001). Do Smarter Teams Do Better? A Meta-Analysis of Cognitive Ability and Team Performance. Small group Research, 32, 507-532.

Fischabcher, U. (2007). z-Tree-Zurich Toolbox for Readymade Economic Experiments, Experimental Economics, 10 (2), 171-178.

Gillet, J., Schram A., and Sonnemans J. The Tragedy of the Commons Revisited: The Importance of Group Decision-Making. Journal of Public Economics, In Press.

Isaac, R. M. and Walker, J. M. (1988). Communication and Free-Riding Behavior: The Voluntary Contribution Mechanism. Economic Inquiry, 26 (4), 585-608.

Keer, N. L., MacCoun, R. J., and Kramer, G. P. (1996a). Bias in Judgments: Comparing Individuals and Groups, Psychological Review, 103, 687-719.

Keer, N. L., MacCoun, R. J., and Kramer, G. P. (1996b). When Are N Heads Better (or Worse) Than One? Biased Judgments in Individuals and Groups, In E. H. Witte \& J. H. Davis (Eds.), Understanding Group Behavior: Consensual Action By Small Groups, 1, 105-136, Mahwah, NJ: Erlbaum.

Kocher, M. G. and Sutter, M. (2005). The Decision Maker Matters: Individual versus Group Behavior in Experimental Beauty-Contest Games, Economic Journal, 115(500), 200-223.

Hackett, S., Schlager, E. and Walker, J. (1994). The Role of Communication in Resolving Commons Dilemmas: Experimental Evidence with Heterogenous Appropriators, Journal of Environmental Economics and Management, 27, 99-126.

Harrison, Glenn W., Igel Lau, Morton, Rutström, E. Elisabet, and Tarazona-Gómez, Marcela (2005). Preferences Over Social Risk, unpublished manuscript.

Lamm, H. and Myers, D. G. (1978), Group-induced Polarization of Attitudes and Behavior, Advances in Experimental Social Psychology, 11, 145-195. 
Laughlin, P. R., Bonner, B. L., and Miner, A. G. (2002), Groups Perform Better Than the Best Individuals on Letters-to-numbers Problems, Organizational Behavior and Human Decision Processes, 61, 94-107.

Laughlin, P. R., Zander, M. L., Knievel, E. M., and Tan, T. K. (2003), Groups Perform Better than the Best Individuals on Letters-to-numbers Problems: Informative Equations and Effective Strategies, Journal of Personality and Social Psychology, 85, 684-694.

Masclet, D., Loheac, Y., Laurent, D.-B. and Colombier, N. (2009), Group and Individual Risk Preferences : A Lottery-Choice Experiment, forthcoming in Journal of Economic Behavior and Organization

Pruitt, D. G. (1971), Choice Shifts in Group Discussion: An Introductory Review. Journal of Personality and Social Psychology, 20, 339-360.

Rockenbach, B., Sadrieh, A. and Mathauschek, B. (2007), Teams Take the Better Risks, Journal of Economic Behavior and Organization, 63, 412-422.

Shupp, R. and Williams, A. W. (2008), Risk Preference Differentials of Small Groups and Individuals, The Economic Journal, 118 (525-01), 258-283.

Stasser, G. and Dietz-Uhler, B. (2001), Collective Choice, Judgment, and Problem Solving, In M. A. Hogg \& R. S. Tindale (Eds.), Blackwell Handbook of Social Psychology: Group Processes, 31-55, Malden, MA: Blackwell.

Steiner, I. D. (1972), Group Processes and Productivity. New York: Academic Press.

Stoner, J. A. F. (1961), A Comparison of Individual and Group Decisions Under Risk, Unpublished Master's Thesis, Massachusetts Institute of Technology, School of Management.

Sutter, Matthias (2005), Are Four Heads Better than Two? An Experimental Beauty-Contest Game with Teams of Different Sizes, Economics Letters, 88, 41-46. 
Table 1: Design comparison across five studies of group lottery choices

\begin{tabular}{|c|c|c|c|c|c|c|c|c|}
\hline & $\begin{array}{l}\text { Includes } \\
\text { between- } \\
\text { subject } \\
\text { design }\end{array}$ & $\begin{array}{l}\text { Number of } \\
\text { groups in } \\
\text { the } \\
\text { experiment }\end{array}$ & $\begin{array}{c}\text { Group } \\
\text { composition } \\
\text { across } \\
\text { choices }\end{array}$ & $\begin{array}{c}\text { Every } \\
\text { individual } \\
\text { posts a } \\
\text { non- } \\
\text { binding } \\
\text { proposal }\end{array}$ & $\begin{array}{l}\text { Default } \\
\text { choice } \\
\text { when no } \\
\text { group } \\
\text { unanimity }\end{array}$ & $\begin{array}{l}\text { Maximum } \\
\text { attempts } \\
\text { to reach } \\
\text { group } \\
\text { choice }\end{array}$ & Communication & $\begin{array}{c}\text { Positive } \\
\text { incentives } \\
\text { to } \\
\text { talk/listen } \\
\text { to others }\end{array}$ \\
\hline $\begin{array}{l}\text { Zhang et } \\
\text { al., 2009 } \\
\text { [This } \\
\text { study] }\end{array}$ & no & 40 & fixed & yes & $\begin{array}{c}\text { None } \\
\text { (zero } \\
\text { earnings) }\end{array}$ & 3 & Chat (2 min.) & yes/yes \\
\hline $\begin{array}{l}\text { Masclet } \\
\text { et al., } \\
2009\end{array}$ & no & 36 & random & no & Random & 5 & None & yes/no \\
\hline $\begin{array}{c}\begin{array}{c}\text { Shupp } \\
\text { and } \\
\text { Williams, } \\
2007\end{array}\end{array}$ & yes & 28 & fixed & no & $\begin{array}{c}\text { Mean of } \\
\text { individual } \\
\text { bids }\end{array}$ & 1 & $\begin{array}{l}\text { Face-to-face } \\
\text { (20 min.) }\end{array}$ & yes/no $(*)$ \\
\hline $\begin{array}{l}\text { Baker et } \\
\text { al., } 2008\end{array}$ & yes & 40 & fixed & no & $\begin{array}{l}\text { Majority } \\
\text { rule }\end{array}$ & 1 & Face-to-face & $\begin{array}{c}\text { yes for } \\
\text { minority/no }\end{array}$ \\
\hline $\begin{array}{l}\text { Harrison } \\
\text { et al., } \\
2005\end{array}$ & no & 36 & fixed & no & $\begin{array}{l}\text { Majority } \\
\text { rule }\end{array}$ & 1 & None & $\begin{array}{c}\text { yes for } \\
\text { minority/no }\end{array}$ \\
\hline
\end{tabular}

Notes: (*) It may be "yes/yes," a short explanation follows. Shupp and Williams (2007) asked to price each lottery and then awarded the lottery using an incentive compatible mechanism. The default bid without unanimity is the average of individual bids. Notice that an individual player may have an incentive to manipulate the group price by strategically over- or under-bidding in order to generate a group bid closer to her preferred level 
Table 2: Lottery choice task

\begin{tabular}{|c|c|c|c|c|c|c|c|c|}
\hline & $\begin{array}{c}\text { Option } \\
A\end{array}$ & & $\begin{array}{c}\text { Option } \\
B\end{array}$ & & Risk Preference & $\begin{array}{l}\text { Individual } \\
\text { Choices }\end{array}$ & $\begin{array}{l}\text { Individual } \\
\text { Proposals }\end{array}$ & $\begin{array}{l}\text { Group } \\
\text { Choices }\end{array}$ \\
\hline \multirow[t]{2}{*}{$\begin{array}{l}\text { Decision } \\
\text { node }\end{array}$} & \multirow[t]{2}{*}{ Payoffs } & \multirow[t]{2}{*}{ Payoffs } & \multirow[t]{2}{*}{$\begin{array}{c}\text { Probability } \\
\text { of getting } \\
150 \text { tokens }\end{array}$} & \multirow[t]{2}{*}{$\begin{array}{l}\text { Expected } \\
\text { payoff of } \\
\text { option B }\end{array}$} & \multirow{2}{*}{$\begin{array}{c}\text { Range of CRRA } \\
\text { If switch from A } \\
\text { to } B \text { at the fol- } \\
\text { lowing decision } \\
\text { node }\end{array}$} & $\begin{array}{l}\text { Frequency } \\
\text { of choices } \\
\text { for B }\end{array}$ & $\begin{array}{l}\text { Frequency } \\
\text { of choices } \\
\text { for B }\end{array}$ & $\begin{array}{l}\text { Frequency } \\
\text { of choices } \\
\text { for B }\end{array}$ \\
\hline & & & & & & $(\%)$ & $(\%)$ & $(\%)$ \\
\hline 1 & 50 & $\begin{array}{c}150 \text { or } \\
0 \\
150 \text { or }\end{array}$ & 0 & 0 & $\mathrm{r}<-1.73$ & 0 & 0.8 & 0 \\
\hline 2 & 50 & $\begin{array}{c}0 \\
150 \text { or }\end{array}$ & 0.05 & 7.5 & $-1.73<r<-1.1$ & 0 & 0 & 0 \\
\hline 3 & 50 & $\begin{array}{c}0 \\
150 \text { or }\end{array}$ & 0.1 & 15 & $-1.1<r<-0.73$ & 1.7 & 0 & 0 \\
\hline 4 & 50 & $\begin{array}{c}0 \\
150 \text { or }\end{array}$ & 0.15 & 22.5 & $-0.73<\mathrm{r}<-0.47$ & 0 & 0 & 0 \\
\hline 5 & 50 & $\begin{array}{c}0 \\
150 \text { or }\end{array}$ & 0.2 & 30 & $-0.47<r<-0.27$ & 1.7 & 0 & 0 \\
\hline 6 & 50 & $\begin{array}{c}0 \\
150 \text { or }\end{array}$ & 0.25 & 37.5 & $-0.27<\mathrm{r}<-0.1$ & 5 & 2.5 & 0 \\
\hline 7 & 50 & $\begin{array}{c}0 \\
150 \text { or }\end{array}$ & 0.3 & 45 & $-0.1<\mathrm{r}<0.04$ & 5.8 & 6.7 & 2.5 \\
\hline 8 & 50 & $\begin{array}{c}0 \\
150 \text { or }\end{array}$ & 0.35 & 52.5 & $0.04<\mathrm{r}<0.16$ & 15 & 20 & 16.7 \\
\hline 9 & 50 & $\begin{array}{c}0 \\
150 \text { or }\end{array}$ & 0.4 & 60 & $0.16<\mathrm{r}<0.27$ & 24.2 & 26.7 & 21.7 \\
\hline 10 & 50 & $\begin{array}{c}0 \\
150 \text { or }\end{array}$ & 0.45 & 67.5 & $0.27<\mathrm{r}<0.36$ & 31.7 & 32.5 & 36.7 \\
\hline 11 & 50 & $\begin{array}{c}0 \\
150 \text { or }\end{array}$ & 0.5 & 75 & $0.36<\mathrm{r}<0.45$ & 58.3 & 58.3 & 65 \\
\hline 12 & 50 & $\begin{array}{c}0 \\
150 \text { or }\end{array}$ & 0.55 & 82.5 & $0.45<\mathrm{r}<0.53$ & 68.3 & 67.5 & 80 \\
\hline 13 & 50 & $\begin{array}{c}0 \\
150 \text { or }\end{array}$ & 0.6 & 90 & $0.53<\mathrm{r}<0.6$ & 80 & 80 & 87.5 \\
\hline 14 & 50 & $\begin{array}{c}0 \\
150 \text { or }\end{array}$ & 0.65 & 97.5 & $0.6<r<0.66$ & 88.3 & 90.8 & 95 \\
\hline 15 & 50 & 0 & 0.7 & 105 & $0.66<\mathrm{r}$ & 93.3 & 95 & 97.5 \\
\hline & & & ercentage of 1 & otonic deci & n makers & 87.5 & 90 & 95 \\
\hline
\end{tabular}

Notes: Everyone should choose option A in decision 1. Risk neutral subjects would switch to option B in decision 8. A switch in later decisions reveals risk aversion and a switch in earlier decisions reveals risk seeking behavior. Number of observations for each line: 120. 
Table 3: Risk neutrality when disagreement

\begin{tabular}{|c|c|c|c|}
\hline & $\begin{array}{l}\text { Majority } \\
\text { prevailed }\end{array}$ & $\begin{array}{l}\text { Minority } \\
\text { prevailed }\end{array}$ & \\
\hline $\begin{array}{l}\text { Majority at risk } \\
\text { neutrality }\end{array}$ & 79 & 12 & $\begin{array}{c}91 \\
(57.2 \%)\end{array}$ \\
\hline $\begin{array}{c}\text { Minority at risk } \\
\text { neutrality }\end{array}$ & 50 & 18 & $\begin{array}{c}68 \\
(42.8 \%)\end{array}$ \\
\hline Totals & $\begin{array}{c}129 \\
(81.1 \%)\end{array}$ & $\begin{array}{c}30 \\
(18.9 \%)\end{array}$ & $\begin{array}{c}159 \\
(100 \%)\end{array}$ \\
\hline
\end{tabular}

Table 4: Risky shift when disagreement

\begin{tabular}{cccc}
\hline & $\begin{array}{c}\text { Majority } \\
\text { prevailed }\end{array}$ & $\begin{array}{c}\text { Minority } \\
\text { prevailed }\end{array}$ & \\
\hline $\begin{array}{c}\text { Majority more } \\
\text { risky }\end{array}$ & 68 & 11 & $\begin{array}{c}79 \\
(49.7 \%)\end{array}$ \\
$\begin{array}{c}\text { Minority more } \\
\text { risky }\end{array}$ & 61 & 19 & $\begin{array}{c}80 \\
(50.3 \%)\end{array}$ \\
Totals & 129 & 30 & 159 \\
\hline
\end{tabular}

Notes: Group decisions with disagreement only (27.0\% of total). The table compares individual proposals with group choice. The majority proposal was $A$ when $A A B$ and was $B$ when $A B B$. 
Table 5: Probit regression on how groups resolve disagreement (main)

\begin{tabular}{|c|c|c|c|c|c|}
\hline $\begin{array}{l}\text { Sample: decisions with disagreement only } \\
\text { Dependent variable: } \\
1=\text { my proposal equals group choice, } 0=\text { otherwise }\end{array}$ & (1) & $\begin{array}{l}\text { Majority } \\
\text { prevails }\end{array}$ & $\begin{array}{l}\text { Minority } \\
\text { prevails }\end{array}$ & $\begin{array}{l}\text { Multiple at- } \\
\text { tempts be- } \\
\text { fore unanim- } \\
\text { ity } \\
\text { (4) }\end{array}$ & $\begin{array}{l}\text { One at- } \\
\text { tempt be- } \\
\text { fore unan- } \\
\text { imity } \\
\quad(5)\end{array}$ \\
\hline \multicolumn{6}{|l|}{ Independent variables: } \\
\hline My proposal was the risk neutral choice ( 1 or 0 ) & $\begin{array}{c}0.20 * \\
(0.10)\end{array}$ & $\begin{array}{l}0.15^{*} \\
(0.06)\end{array}$ & $\begin{array}{l}0.15^{*} \\
(0.06)\end{array}$ & $\begin{array}{c}0.06 \\
(0.12)\end{array}$ & $\begin{array}{c}0.33 * * \\
(0.12)\end{array}$ \\
\hline My proposal was in the majority ( 1 or 0$)$ & $\begin{array}{l}0.65 * * \\
(0.08)\end{array}$ & & & $\begin{array}{c}0.72 * * \\
(0.16)\end{array}$ & $\begin{array}{c}0.64 * * \\
(0.11)\end{array}$ \\
\hline My individual choice was different than my proposal & $\begin{array}{c}-0.27^{*} \\
(0.13)\end{array}$ & $\begin{array}{l}-0.38^{*} \\
(0.18)\end{array}$ & $\begin{array}{c}0.07 \\
(0.11)\end{array}$ & $\begin{array}{c}-0.37^{* *} \\
(0.12)\end{array}$ & $\begin{array}{c}-0.36^{*} \\
(0.15)\end{array}$ \\
\hline My proposals were not monotonic ( 1 or 0$)$ & $\begin{array}{c}-0.30 * * \\
(0.07)\end{array}$ & $\begin{array}{l}-0.18 \\
(0.10)\end{array}$ & $\begin{array}{l}-0.08 \\
(0.04)\end{array}$ & $\begin{array}{l}-0.13 \\
(0.12)\end{array}$ & $\begin{array}{c}-0.33 * * \\
(0.12)\end{array}$ \\
\hline $\begin{array}{l}\text { Number of lottery decisions on which the group dis- } \\
\text { agree }\end{array}$ & $(0.01)$ & $(0.01)$ & $(0.02)$ & $(0.04)$ & $(0.01)$ \\
\hline Multiple attempts to decide ( 1 or 0 ) & $\begin{array}{l}0.05 \\
(0.05)\end{array}$ & $\begin{array}{c}0.04 \\
(0.03)\end{array}$ & $\begin{array}{l}-0.07 \\
(0.07)\end{array}$ & & \\
\hline Chat messages & & & & & \\
\hline I talked first ( 1 or 0$)$ & $\begin{array}{c}0.09 \\
(0.07)\end{array}$ & $\begin{array}{c}0.09 * * \\
(0.04)\end{array}$ & $\begin{array}{c}0.12 \\
(0.09)\end{array}$ & $\begin{array}{l}-0.08 \\
(0.13)\end{array}$ & $\begin{array}{c}0.00 \\
(0.08)\end{array}$ \\
\hline I talked last $(1$ or 0$)$ & $\begin{array}{l}-0.09 \\
(0.06)\end{array}$ & $\begin{array}{l}-0.04 \\
(0.03)\end{array}$ & $\begin{array}{l}-0.06 \\
(0.05)\end{array}$ & $\begin{array}{l}0.20^{*} \\
(0.10)\end{array}$ & $\begin{array}{l}-0.13 \\
(0.08)\end{array}$ \\
\hline Number of words I wrote in my group (x 100) & $\begin{array}{l}0.15 \\
(0.46)\end{array}$ & $\begin{array}{l}-0.23 \\
(0.18)\end{array}$ & $\begin{array}{l}0.53 * \\
(0.21)\end{array}$ & $\begin{array}{c}0.82 \\
(0.58)\end{array}$ & $\begin{array}{c}0.23 \\
(0.59)\end{array}$ \\
\hline Number of words that all other members wrote (x 100) & $\begin{array}{l}-0.40 \\
(0.24)\end{array}$ & $\begin{array}{c}-0.38 * * \\
(0.10)\end{array}$ & $\begin{array}{c}0.17 \\
(0.17)\end{array}$ & $\begin{array}{c}-0.46^{* *} \\
(0.14)\end{array}$ & $\begin{array}{l}-0.36 \\
(0.32)\end{array}$ \\
\hline Demographics & & & & & \\
\hline Science and Engineering Major ( 1 or 0$)$ & $\begin{array}{c}0.08 \\
(0.08)\end{array}$ & $\begin{array}{c}0.06 \\
(0.03)\end{array}$ & $\begin{array}{l}-0.05 \\
(0.07)\end{array}$ & $\begin{array}{c}0.20 \\
(0.11)\end{array}$ & $\begin{array}{c}0.04 \\
(0.09)\end{array}$ \\
\hline Male who is above 75 percentile SAT/ACT ( 1 or 0$)$ & $\begin{array}{c}0.02 \\
(0.07)\end{array}$ & $\begin{array}{c}0.00 \\
(0.05)\end{array}$ & $\begin{array}{l}-0.04 \\
(0.05)\end{array}$ & $\begin{array}{l}-0.02 \\
(0.21)\end{array}$ & $\begin{array}{l}0.17 * * \\
(0.06)\end{array}$ \\
\hline Female who is above 75 percentile SAT/ACT ( 1 or 0$)$ & $\begin{array}{c}0.11 \\
(0.12)\end{array}$ & $\begin{array}{c}0.08 * * \\
(0.03)\end{array}$ & $\begin{array}{l}-0.02 \\
(0.12)\end{array}$ & $\begin{array}{l}-0.21 \\
(0.16)\end{array}$ & $\begin{array}{c}0.29 * * \\
(0.09)\end{array}$ \\
\hline Male who is below 25 percentile SAT/ACT ( 1 or 0$)$ & $\begin{array}{c}0.08 \\
(0.09)\end{array}$ & $\begin{array}{c}0.08 * * \\
(0.02)\end{array}$ & $\begin{array}{c}0.12 \\
(0.14)\end{array}$ & $\begin{array}{l}0.15^{*} \\
(0.07)\end{array}$ & $\begin{array}{c}0.10 \\
(0.11)\end{array}$ \\
\hline Female who is below 25 percentile SAT/ACT ( 1 or 0 ) & $\begin{array}{c}0.12 \\
(0.11)\end{array}$ & $\begin{array}{l}0.07 * \\
(0.03)\end{array}$ & $\begin{array}{c}0.02 \\
(0.13)\end{array}$ & $\begin{array}{l}-0.36^{*} \\
(0.17)\end{array}$ & $\begin{array}{l}0.33 * * \\
(0.05)\end{array}$ \\
\hline Missing demographic data ( 1 or 0 ) & $\begin{array}{c}0.09 \\
(0.08)\end{array}$ & $\begin{array}{c}0.06 \\
(0.03)\end{array}$ & $\begin{array}{l}-0.03 \\
(0.06)\end{array}$ & $\begin{array}{l}-0.46 \\
(0.30)\end{array}$ & $\begin{array}{l}0.19^{*} \\
(0.09)\end{array}$ \\
\hline Personality traits & & & & & \\
\hline Agreeableness & $\begin{array}{c}0.00 \\
(0.05)\end{array}$ & $\begin{array}{c}0.01 \\
(0.03)\end{array}$ & $\begin{array}{c}0.04 \\
(0.04)\end{array}$ & $\begin{array}{c}0.08 \\
(0.11)\end{array}$ & $\begin{array}{l}-0.06 \\
(0.06)\end{array}$ \\
\hline Conscientiousness & $\begin{array}{l}-0.11 \\
(0.06)\end{array}$ & $\begin{array}{c}-0.09 * * \\
(0.04)\end{array}$ & $\begin{array}{l}-0.01 \\
(0.07)\end{array}$ & $\begin{array}{c}0.15 \\
(0.13)\end{array}$ & $\begin{array}{l}-0.13 \\
(0.09)\end{array}$ \\
\hline Neuroticism & $\begin{array}{l}-0.01 \\
(0.06)\end{array}$ & $\begin{array}{c}-0.04 \\
(0.03)\end{array}$ & $\begin{array}{l}-0.00 \\
(0.05)\end{array}$ & $\begin{array}{c}0.12 \\
(0.18)\end{array}$ & $\begin{array}{l}-0.05 \\
(0.07)\end{array}$ \\
\hline Openness & $\begin{array}{c}0.02 \\
(0.05)\end{array}$ & $\begin{array}{l}-0.01 \\
(0.03)\end{array}$ & $\begin{array}{l}-0.01 \\
(0.05)\end{array}$ & $\begin{array}{c}0.11 \\
(0.10)\end{array}$ & $\begin{array}{c}0.04 \\
(0.06)\end{array}$ \\
\hline Extroversion & $\begin{array}{l}-0.00 \\
(0.05)\end{array}$ & $\begin{array}{l}-0.00 \\
(0.02)\end{array}$ & $\begin{array}{l}-0.00 \\
(0.06)\end{array}$ & $\begin{array}{l}0.15^{*} \\
(0.08)\end{array}$ & $\begin{array}{l}-0.03 \\
(0.05) \\
\end{array}$ \\
\hline $\begin{array}{l}\text { Number of observations } \\
\text { Pseudo R-squared } \\
\text { Log likelihood }\end{array}$ & $\begin{array}{c}477 \\
-204.5 \\
0.362\end{array}$ & $\begin{array}{c}318 \\
-109.0 \\
0.292\end{array}$ & $\begin{array}{c}159 \\
-61.17 \\
0.206\end{array}$ & $\begin{array}{c}150 \\
-49.06 \\
0.507\end{array}$ & $\begin{array}{c}327 \\
-137.3 \\
0.378\end{array}$ \\
\hline
\end{tabular}

Notes: marginal effects; Robust standard errors in parentheses, clusters on groups.

Statistical significance $* * p<0.01, * p<0.05$. Sample: decisions with disagreement only. The regression includes lottery decision dummies, which have not been reported in the table. One group did not agree on 3 lottery decisions and those decisions are excluded from this table. 
Table 6: Probit regression on group difficulty of reaching an agreement

Sample: decisions with disagreement only

Dependent variable:

$1=$ my group required more than one attempt to decide; $0=$ otherwise

Independent variables:

my proposal was the risk neutral choice $(0 / 1)$

0.00

$(0.05)$

my individual choice was different than my proposal

0.05

my proposals were not monotonic $(0 / 1)$

(0.11)

$0.36 * *$

(0.16)

number of lotteries with disagreement in the group

$0.17 * * *$

number of words written overall by group (x 100)

$(0.05)$

$-0.52 *$

(0.30)

number of words written in the last intervention (x 100)

0.01

number of words written in the second to last intervention (x 100)

(0.02)

$0.04 * * *$

difference in words spoken between the most and the least individual in a group ( $\mathrm{x}$

100)

$1.22 * *$

(0.59)

Science and Engineering Major

$-0.25 * *$

(0.11)

MALE who is above 75 percentile SAT/ACT

$-0.20 * *$

$(0.08)$

$-0.12 *$

FEMALE who is above 75 percentile SAT/ACT

$(0.07)$

MALE who is below 25 percentile SAT/ACT

0.05

$(0.14)$

FEMALE who is below 25 percentile SAT/ACT

$-0.01$

$(0.13)$

Missing data

0.05

$(0.12)$

agreeableness

$-0.02$

(0.06)

conscientiousness

$-0.17 * *$

(0.08)

neuroticism

0.01

(0.07)

openness

$-0.12$

(0.08)

extroversion

\begin{tabular}{lc} 
Observations & 477 \\
Pseudo R-squared & 0.519 \\
Log likelihood & -142.8 \\
\hline
\end{tabular}

Notes: marginal effects; Robust standard errors in parentheses, clusters on groups. Statistical significance ${ }^{* *} p<0.01,{ }^{* *} p<0.05, * p<0.1$. Sample: decisions with disagreement only. The regression includes lottery decision dummies, which have not been reported in the table. 
Figure 1: Individual versus Group risk attitude.

Fraction of risky lottery choices by groups and individuals

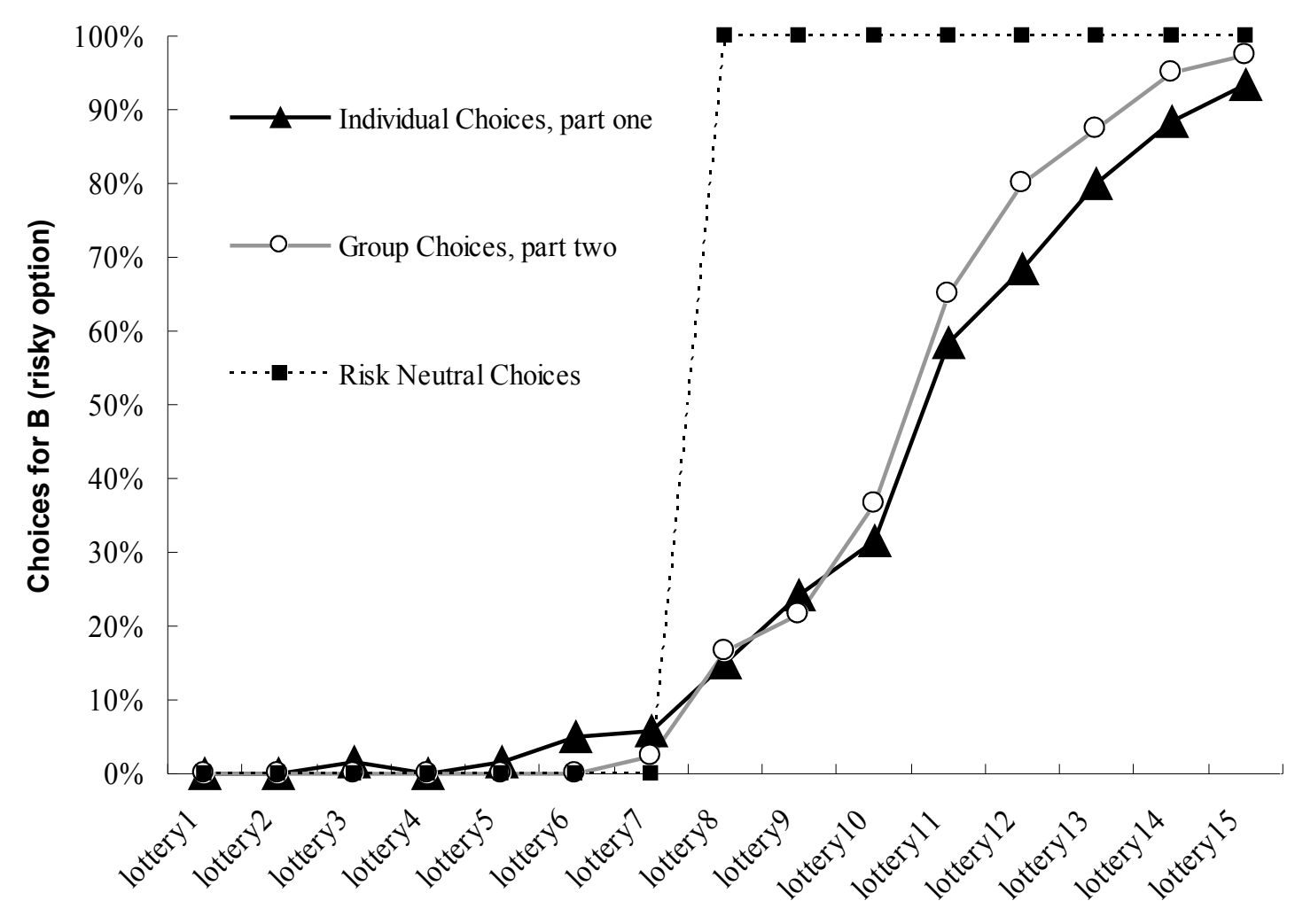

Notes: $N=120$. One group did not agree on 3 lottery decisions. For those decisions, the graph employed their individual third attempt proposals. Lottery numbers are the same as in Table 2. 
Figure 2: Group classification by number of decisions in disagreement $(\mathrm{N}=40)$

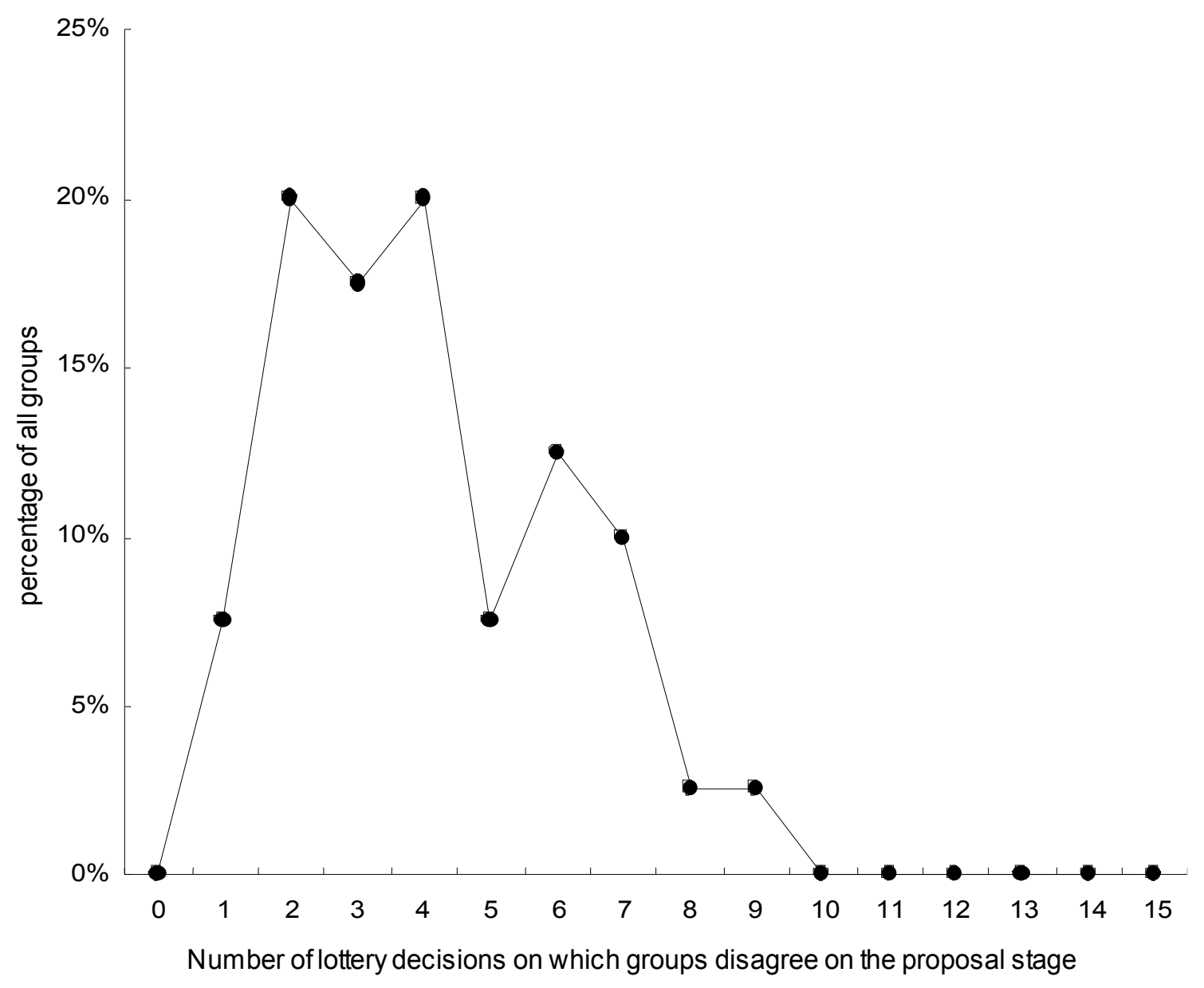


Figure 3: Which lottery decisions were most controversial.

Disagreement within groups for each lottery $(\mathrm{N}=600)$

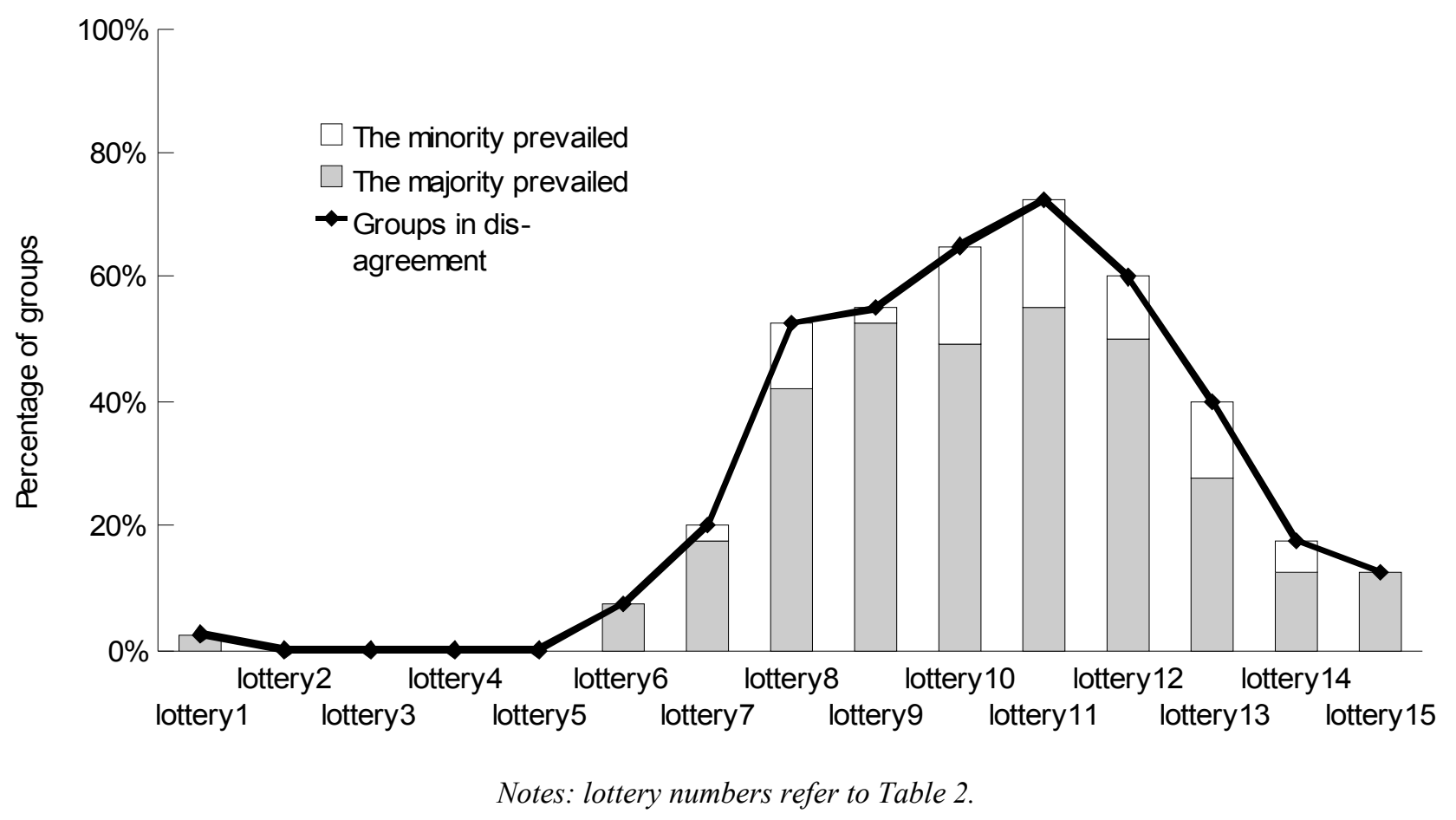


Figure 4: Chat activity $(\mathrm{N}=40)$

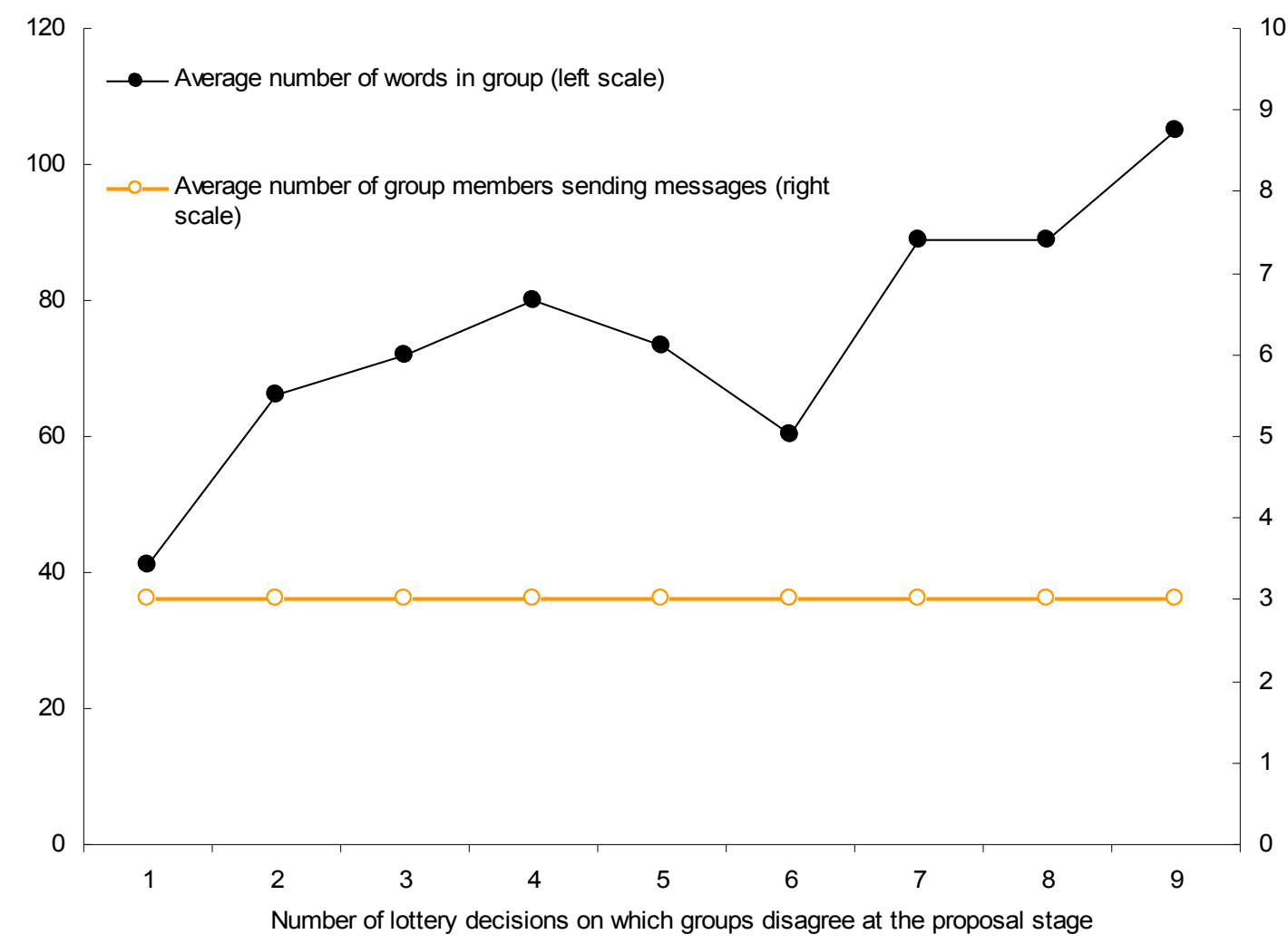


Figure 5: One hundred most frequent words in chat messages

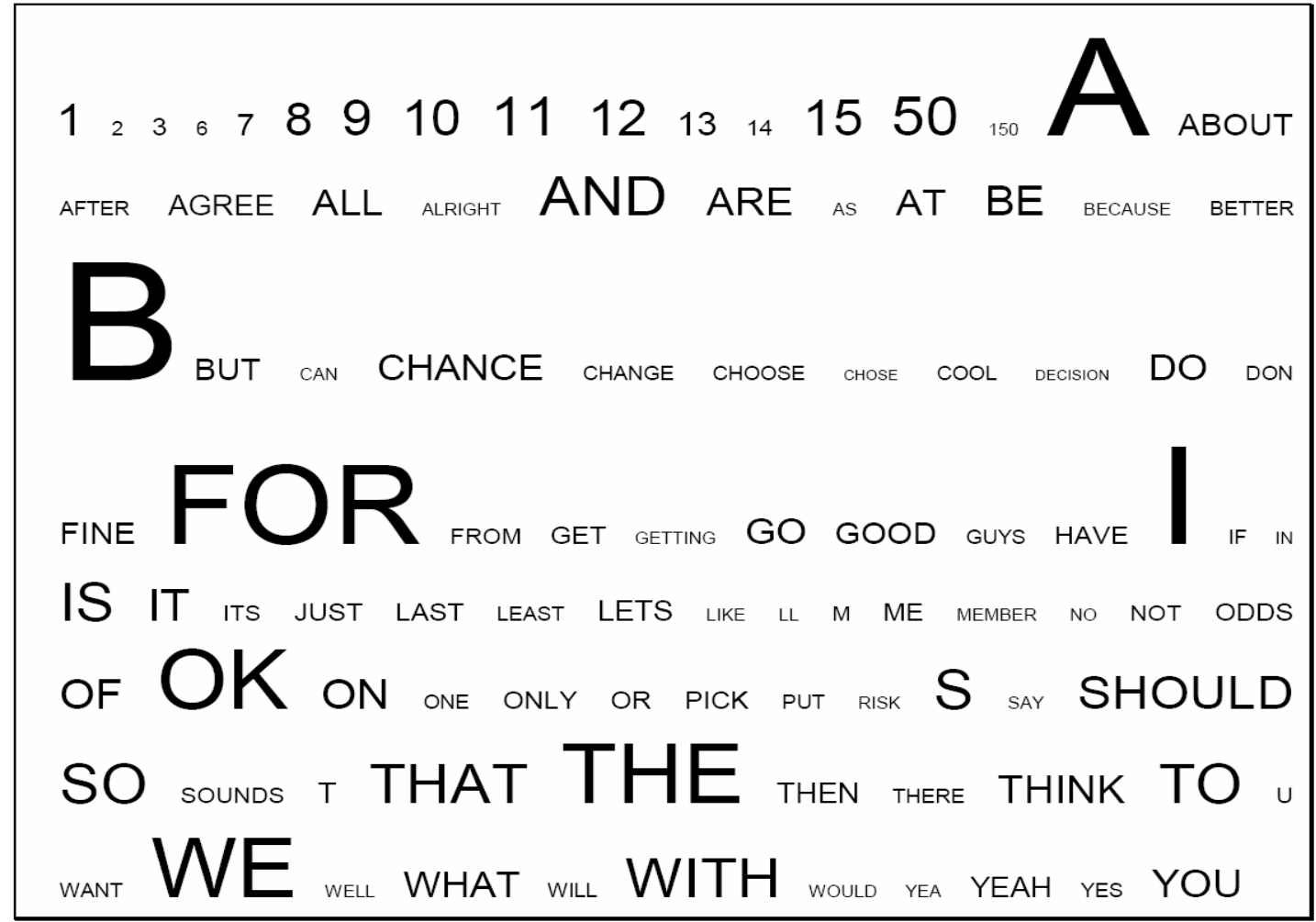

Notes: " $B$ " is the most frequently used (122 times) "DECISION" is the least used (7 times). Character size is proportional to frequency of use 
[For the referee only] Table 5B: How groups resolve disagreement (robustness check)

Dependent variable:

$1=$ my proposal equals group choice, $0=$ otherwise

Independent variables:

My proposal was more risky than the alternative choice (1 or 0$)$

My proposal was in the majority ( 1 or 0$)$

My individual choice was different than my proposal

My proposals were not monotonic (1 or 0$)$

Number of lottery decisions on which the group disagree

Multiple attempts to decide ( 1 or 0$)$

Chat messages

I talked first ( 1 or 0$)$

I talked last ( 1 or 0$)$

Number of words I wrote in my group (x 100)

Number of words that all other members wrote (x 100)

Demographics

Science and Engineering Major (1 or 0)

Male who is above 75 percentile SAT/ACT ( 1 or 0$)$

Female who is above 75 percentile SAT/ACT ( 1 or 0 )

Male who is below 25 percentile SAT/ACT ( 1 or 0$)$

Female who is below 25 percentile SAT/ACT ( 1 or 0$)$

Missing demographic data ( 1 or 0$)$

Personality traits

Agreeableness

Conscientiousness

Neuroticism

Openness

Extroversion

Number of observations

Pseudo R-squared

Log likelihood
All

$\begin{array}{cc}\begin{array}{c}\text { Majority } \\ \text { prevails }\end{array} & \begin{array}{c}\text { Minority } \\ \text { prevails }\end{array}\end{array}$

(1)

0.16

(2)

(3)

$0.13^{* *}$

$0.14 *$

(0.05)

$(0.11)$

$0.67 * *$

$(0.08)$

$-0.27 *$

(0.13)

$-0.31 * *$

$(0.07)$

$-0.00$

$(0.01)$

0.04

$(0.05)$

$-\frac{2}{2}$

(0.05)

$-0.38 *$

(0.18)

$-0.17$

(0.10)

0.00

(0.01)

0.04

(0.03)

0.08

$(0.07)$

$-0.09$

(0.06)

0.12

(0.45)

$-0.39$

(0.24)

$0.09 * *$

$(0.03)$

$-0.04$

(0.03)

$-0.23$

(0.18)

$-0.36 * *$

(0.09)

0.07

(0.08)

0.03

$(0.07)$

0.09

(0.12)

0.08

(0.08)

0.12

(0.10)

0.10

(0.08)

0.06

(0.03)

0.00

(0.04)

$0.07 * *$

(0.03)

$0.08 * *$

(0.02)

$0.07 *$

(0.03)

0.06

(0.03)

$\begin{array}{ll}0.00 & 0.01\end{array}$

(0.04)

$-0.11$

(0.06)

$-0.01$

(0.06)

0.02

(0.05)

$-0.00$

$(0.05)$

477

0.354

$-207.1$
0.01
$(0.03)$

$-0.09 * *$

(0.03)

$-0.04$

(0.03)

$-0.01$

(0.03)

$-0.00$

(0.02)

318

0.292

$-109.0$
0.07

(0.12)

$-0.08$

$(0.04)$

$-0.00$

$-0.07$

(0.07)

0.12

(0.09)

$-0.06$

(0.05)

0.53 *

$(0.21)$

0.17

(0.17)

$(0.07)$

$-0.04$

$0.05)$

$-0.02$

(0.12)

0.12

(0.14)

0.02

$(0.13)$

$-0.03$

(0.06)

\subsection{4}

$$
\text { (0.04) }
$$

$(0.04)$
-0.01

(0.07)

$-0.00$

(0.05)

$-0.01$

(0.05)

$-0.00$

159

0.206

$-61.17$
Multiple

attempts

before un-

animity

(4)

0.05

(0.11)

(0.12)

$0.73 * * \quad 0.65 * *$

(0.15)

(0.11)

$-0.35 * *$

$-0.36^{*}$

(0.11)

(0.15)

$-0.15$

$-0.33 * *$

$(0.10)$

$(0.12)$

$-0.04$

(0.04)

(0.01)

$-0.09$

0.00

$(0.10)$

$(0.08)$

0.20 *

(0.09)

$-0.14$

0.85

(0.08)

$(0.55)$

$-0.48 * *$

0.19

$(0.55)$

(0.12)

(0.31)

$0.19 *$

0.03

(0.09)

$-0.03$

$(0.09)$

(0.26)

$0.15^{* *}$

$-0.22$

(0.06)

$(0.20)$

$0.27 * *$

0.15

$(0.10)$

0.10

(0.09)

(0.11)

$0.32 * *$

(0.05)

(0.17)

0.20 *

$-0.46$

(0.09)
0.08

(0.11)

0.13

(0.10)

0.13

(0.15)

0.11

(0.08)

0.14

(0.08)

$-0.04$

(0.06)

$-0.12$

(0.09)

$-0.04$

(0.07)

0.03

(0.05)

$-0.04$ (0.05)

327

150

0.507

0.357

$-141.9$

Notes: see notes to Table 5. This regression includes "My proposal was more risky than the alternative choice” in alternative to "My proposal was the risk neutral choice" as they are highly correlated. 


\section{Not for publication}

\section{COPY OF THE INSTRUCTIONS [EXCTRACT]}

This experiment deals with the economics of decision making under uncertainty. Various agencies have provided funds for the experiment. If you follow these instructions and make good decisions, you can earn a significant amount of money, which you will receive in cash, privately at the end of the experiment.

Earnings are in tokens, each token is worth $\$ 0.03$. You are guaranteed a minimum payment of $\$ 5$ but will most likely earn more. The experiment is divided into four parts. You will be paid the sum of your earnings from all parts. The table below will help you to keep track of your earnings.

\section{EARNINGS TABLE}

Part 1
Part 2
Part 3
Part 4
Total in tokens
Total in dollars (conversion rate 1 token $=\$ 0.03$ )

The tasks in part 1 and part 2 are identical. We are now reading the instructions for part 1.

\section{INSTRUCTIONS FOR PART 1}

Please look at the table in the next page. For each decision, state whether you prefer option A or option B. Your earnings depend on which option you choose: if you choose option A, you will receive 50 tokens for sure. If you choose option B, you will receive either 150 tokens or 0 tokens depending on the results of a random draw.

Notice that there are a total of 15 decisions but just one decision in the table will be randomly selected for payment. When you make your choices, you don't know which decision will be paid. Hence you should pay attention to every decision. At the end of the session, we will randomly draw a number from 1 to 15 to select a decision. Each number is equally likely.

In the decision selected for payment, you may have chosen either option A or B. If you chose A, you will receive 50 tokens. If you chose B, we will do a second random draw. Every number from 1 to 20 is equally likely. This second number is then compared with the numbers for option B in the table. If the number shows up in the left column of the decision selected you earn 150 tokens. If the number shows up in the right column you earn 0 tokens.

We ask you to make the choices on paper and then to input them into the computer as well.

Now it is time for clarifications. Are there any questions?

Before proceeding we ask that you complete a short quiz below.

Quiz

1. If at the end of the experiment, we first draw number 2 and then we draw number 1 , what are your earnings?

In case my choice for decision 2 was A tokens

In case my choice for decision 2 was $\mathrm{B}$ tokens

2. If at the end of the experiment, we first draw number 14 and then we draw number 14 again what are your earnings?

In case my choice for decision 14 was $\mathrm{A}$ tokens

In case my choice for decision 14 was $B$ tokens 


\begin{tabular}{|c|c|c|c|c|}
\hline $\begin{array}{l}\text { Decisi } \\
\text { on no. }\end{array}$ & Option A & (left column) & $\begin{array}{l}\text { Option } \\
\text { B } \\
\text { (right column) }\end{array}$ & $\begin{array}{l}\text { Please } \\
\text { choose A } \\
\text { or B }\end{array}$ \\
\hline 1 & 50 tokens & 150 tokens never & $\begin{array}{c}\text { 0 tokens if } 1,2,3,4,5,6,7,8,9,10,11,12,13,14,15, \\
16,17,18,19,20\end{array}$ & \\
\hline 2 & 50 tokens & 150 tokens if 1 comes out of the bingo cage & $\begin{array}{l}\mathbf{0} \text { tokens if } 2,3,4,5,6,7,8,9,10,11,12,13,14,15 \\
16,17,18,19,20\end{array}$ & \\
\hline 3 & 50 tokens & 150 tokens if 1 and 2 & $\begin{array}{c}\mathbf{0} \text { tokens if } 3,4,5,6,7,8,9,10,11,12,13,14,15, \\
16,17,18,19,20\end{array}$ & \\
\hline 4 & 50 tokens & $\mathbf{1 5 0}$ tokens if 1,2 and 3 & $\begin{array}{l}\mathbf{0} \text { tokens if } \\
4,5,6,7,8,9,10,11,12,13,14,15,16,17,18,19,20\end{array}$ & \\
\hline 5 & 50 tokens & 150 tokens if $1,2,3,4$ & $\begin{array}{l}\mathbf{0} \text { tokens if } \\
5,6,7,8,9,10,11,12,13,14,15,16,17,18,19,20 \\
\end{array}$ & \\
\hline 6 & 50 tokens & 150 tokens if $1,2,3,4,5$ & $\begin{array}{l}\mathbf{0} \text { tokens if } \\
\quad 6,7,8,9,10,11,12,13,14,15,16,17,18,19,20 \\
\end{array}$ & \\
\hline 7 & 50 tokens & 150 tokens if $1,2,3,4,5,6$ & $\begin{array}{l}\text { 0 tokens if } \\
7,8,9,10,11,12,13,14,15,16,17,18,19,20 \\
\end{array}$ & \\
\hline 8 & 50 tokens & 150 tokens if $1,2,3,4,5,6,7$ & $\begin{array}{l}\mathbf{0} \text { tokens if } \\
8,9,10,11,12,13,14,15,16,17,18,19,20 \\
\end{array}$ & \\
\hline 9 & 50 tokens & 150 tokens if $1,2,3,4,5,6,7,8$ & $\mathbf{0}$ tokens if $9,10,11,12,13,14,15,16,17,18,19,20$ & \\
\hline 10 & 50 tokens & 150 tokens if $1,2,3,4,5,6,7,8,9$ & $\mathbf{0}$ tokens if $10,11,12,13,14,15,16,17,18,19,20$ & \\
\hline 11 & 50 tokens & 150 tokens if $1,2,3,4,5,6,7,8,9,10$ & $\mathbf{0}$ tokens if $11,12,13,14,15,16,17,18,19,20$ & \\
\hline 12 & 50 tokens & 150 tokens if $1,2,3,4,5,6,7,8,9,10,11$ & $\mathbf{0}$ tokens if $12,13,14,15,16,17,18,19,20$ & \\
\hline 13 & 50 tokens & 150 tokens if $1,2,3,4,5,6,7,8,9,10,11,12$ & $\mathbf{0}$ tokens if $13,14,15,16,17,18,19,20$ & \\
\hline 14 & 50 tokens & 150 tokens if $1,2,3,4,5,6,7,8,9,10,11,12,13$ & $\mathbf{0}$ tokens if $14,15,16,17,18,19,20$ & \\
\hline 15 & 50 tokens & 150 tokens if $1,2,3,4,5,6,7,8,9,10,11,12,13,14$ & $\mathbf{0}$ tokens if $15,16,17,18,19,20$ & \\
\hline
\end{tabular}

\section{INSTRUCTIONS FOR PART 2}

You will now face the same decisions as in part 1, but this time you will be in a group with two other participants.

On the first screen, you will input your proposals for the 15 decisions for others in your group to see on their screens. When you click "Submit," all proposals of your group members will be posted on the screen for you to see. From the screen you will see if your group members made the same or different proposals.

At this point, you will be able to send messages to people in your group. To see how, please click now on the messenger tab in the lower portion of your screen. The messenger window will open. Then click on the lower (white) part of the box and type "hello". Please everyone type "hello" now. Then click the 'Send' button, so that others in your group can read your message. If you look at the messenger window you will see how many seconds remain for exchanging messages. The messenger window will be active for two minutes during the task when you start to make decisions for money. Now please switch to the main window by clicking on the background.

Although we will record the messages your group sends to each other, only the people in your group will see them. In sending messages, you should follow two basic rules: (1) Be civil to one another and do not use profanities, and (2) Do not identify yourself in any manner. The communication channel is intended to discuss your choices and should be used that way.

Remember to click the 'Send' button after typing your message. This is VERY important. If you do not click the "Send" button, then your message will not be sent. Therefore, ALWAYS click on the "Send" button after typing in your messages. Also, it is very important that you do not close any window at any time because that will cause delays and problems with the software. If you like, you can simply wait without sending any message, although the messages may help you to agree on a common choice for the group.

After the exchange of messages, you will make your final choices of A or B for the group and then press the 'Submit' button. Your earnings depend on which options you choose and on new random draws. The procedure for payment is the same as in the previous task. Just one decision in the table will be randomly selected for payment at the end of the session. 
If all three people in the group made the same choice in all decisions, those will be the group decisions. If some choices are different, you will be able to revise them in a second round. If some of the choices are still different after the second round, you will be able to revise again the choice in a third round.

If the group does not reach unanimity by the third round, the group may lose the opportunity to earn tokens. More precisely, if a decision with disagreement is randomly selected for payment, the group will always earn zero.

At the very end of part 2, remember to record the final group decisions in the table on the next page. For each decision, state whether the group agreed on option A, option B, or whether there was still disagreement by the third round.

Now it is time for clarifications. Are there any questions?

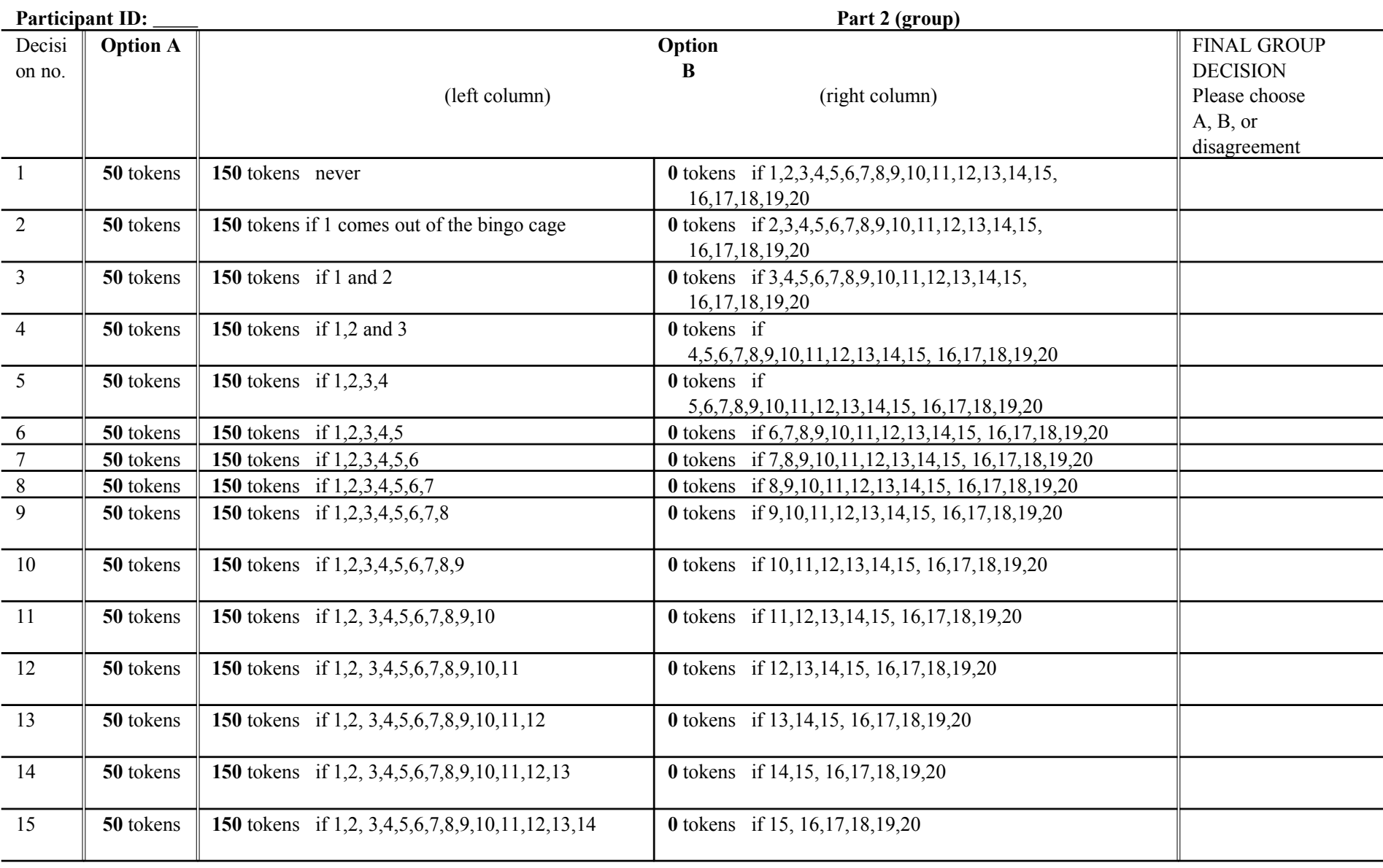

